(c) American Dairy Science Association, 2007.

\title{
The Milk Yield Response to Frequent Milking in Early Lactation of Dairy Cows Is Locally Regulated
}

\author{
E. H. Wall and T. B. McFadden ${ }^{1}$ \\ Lactation and Mammary Gland Biology Group, Department of Animal Science, University of Vermont, Burlington 05405
}

\section{ABSTRACT}

Frequent milking during early lactation of dairy cows increases milk production throughout lactation; however, whether this response is regulated systemically via lactogenic hormones, locally in the mammary gland, or both is unknown. We hypothesized that the effects of frequent milking on milk production during early lactation are regulated via local mechanisms. Ten multiparous cows were assigned at parturition to unilateral frequent milking [UFM; twice daily milking of the left udder half $(2 \times)$, or 4 times daily milking of the right udder half $(4 \times)$ ] for $d 1$ to 21 of lactation. After treatment, cows were milked twice daily for the remainder of lactation. At the first milking after calving, milk yield from individual quarters was measured to verify that udder halves produced equal amounts of milk prior to treatment. Thereafter, individual quarters were milked on $\mathrm{d} 3$ and 7 , weekly for the first 5 wk of lactation, and once every 3 mo for the remainder of lactation. During UFM, cows produced $3.9 \pm 0.7 \mathrm{~kg} / \mathrm{d}$ more from the side milked $4 \times$ than the side milked $2 \times$. Upon cessation of treatment, milk production from the side milked $4 \times$ decreased, but remained at $1.8 \pm 0.5 \mathrm{~kg} / \mathrm{d}$ more than the side milked $2 \times$ for the remainder of lactation. After milk yield was corrected to the equivalent of a wholeudder basis, acute milk yield responses to frequent milking were found to be consistent with previous reports. Moreover, we observed greater persistency in the milk yield response, which lasted throughout lactation. We conclude that both immediate and persistent effects on milk production of frequent milking during early lactation are regulated at the level of the mammary gland. Our results demonstrate that UFM is a valid and efficient model for investigating the effects of frequent milking during early lactation in dairy cows.

Key words: frequent milking, local regulation, mammary gland

Received August 24, 2006.

Accepted October 5, 2006.

${ }^{1}$ Corresponding author: Thomas.mcfadden@uvm.edu
INTRODUCTION

Efficient milk production is critical to the success of the dairy industry. Accordingly, there is a constant demand by dairy producers for management tools that help increase the efficiency and economic profitability of their cows. It is well established that frequent milk removal (3 or more times daily) stimulates milk production compared with twice daily milking (Erdman and Varner, 1995). In addition, a critical time exists during early lactation in which frequent milking or suckling can stimulate milk production for the remainder of lactation (Everitt and Phillips, 1971; Bar-Peled et al., 1995; Hale et al., 2003). Hale et al. (2003) reported that frequent milking for just the first 3 wk of lactation was sufficient to elicit a carryover effect on milk production that continued into late lactation, and this result was subsequently confirmed in a field study by Dahl et al. (2004).

The mechanism by which frequent milking enhances milk production is unknown; however, local regulation of milk production in response to frequent milking of half-udders has been reported (Claesson et al., 1959; Morag, 1973; Hillerton et al., 1990). Half-udder designs are extremely powerful because they eliminate variation between animals attributable to environment, nutrition, and genetics. In addition, both udder halves are exposed to the same systemic factors; hence, responses to frequent milking are strictly at the level of the mammary gland. To our knowledge, no frequent milking studies have been performed on half-udders during early lactation in dairy cows. Therefore, whether the carryover effect on milk production is regulated by local factors, systemic factors, or both is unknown. We used a unilateral frequent milking (UFM) model to isolate the effects of frequent milking during early lactation on the mammary gland of dairy cows. We hypothesized that frequent milking during early lactation enhances milk production through local mechanisms. Our objectives were to test this hypothesis as well as to validate the use of a UFM model for future mechanistic and applied experiments. 


\section{MATERIALS AND METHODS}

\section{Animals and Treatments}

Ten multiparous Holstein cows were assigned at parturition to UFM for $d 1$ to 21 of lactation. Cows were housed in a free-stall barn and received water and a TMR ad libitum. Regular milkings took place at 0230 and $1430 \mathrm{~h}$, and the 2 extra milkings (during which only the right udder half was milked) took place at 0530 and $1730 \mathrm{~h}$. After the treatment period, cows were milked twice daily (at 0230 and $1430 \mathrm{~h}$ ) for the remainder of lactation. The University of Vermont Institutional Animal Care and Use Committee approved all animal use.

\section{Quarter Milking}

Quarter milking was performed using a portable milking system with a milking claw designed to collect milk from each quarter into individual vessels. During quarter milking, milk from each quarter was collected into sterile 18.5-L plastic bags (Parish Manufacturing, Indianapolis, IN) and then weighed. At the first milking after calving, milk yield from individual quarters was measured to verify that udder halves produced equal amounts of milk prior to treatment; cows that were unbalanced by $>0.7 \mathrm{~kg}$ were rejected from the study. Thereafter, quarter milking was performed during the afternoon milking ( $1430 \mathrm{~h}$ ) on d 3 and 7 , then weekly for the first $5 \mathrm{wk}$ of lactation and once every 3 mo for the remainder of lactation. Milk samples from each udder half were collected during quarter milking and were analyzed for SCC and percentages of milk fat and milk protein by the Vermont DHIA.

\section{Statistical Analyses}

Statistical analyses were performed using the PROC MIXED procedure of SAS (SAS Inst. Inc., Cary, NC; version 9.1). A paired $t$-test was used to determine whether differences in milk production between udder halves were significant at each quarter milking. Significance was declared at $P<0.05$.

\section{RESULTS}

Quarter milk yields from 4 cows during the first 3 wk of lactation were analyzed to confirm that the front and rear quarters of the udder responded similarly to UFM ( $P>0.90$; Figure 1). After this was confirmed, front and rear quarter milk yields were combined for the remainder of the experiment. The combined milk weights were used to quantify the milk yield response of the right and left udder halves to UFM. Milk produc- tion at the 2 afternoon milkings was recorded for the first $3 \mathrm{wk}$ of lactation to confirm that quarter milk weights were representative of milk production at those milkings.

Cows responded quickly to UFM and produced $2.1 \pm$ $0.1 \mathrm{~kg}$ of milk during each of the extra milkings $(4.3 \pm$ $0.2 \mathrm{~kg} / \mathrm{d}$; Figure 2). Milk production from the left $(\mathbf{2} \times)$ side of the udder was subtracted from that of the right $(4 \times)$ side of the udder to quantify the differential milk production response to UFM. On d 1 of lactation, udder halves produced similar amounts of milk $(P>0.60$; Figure 3). During UFM, milk production from the $4 \times$ side of the udder increased dramatically and was $3.5 \pm$ $0.2 \mathrm{~kg} / \mathrm{d}$ greater than that of the $2 \times$ udder half $(P<$ 0.001 ; Figure 3). Immediately following cessation of UFM, milk production from the $4 \times$ udder half decreased $(P<0.01)$. Despite the decrease in milk production following cessation of UFM, the $4 \times$ udder half continued to produce $1.8 \pm 0.2 \mathrm{~kg} / \mathrm{d}$ more milk than the $2 \times$ udder half for the remainder of lactation $(P<0.01$; Figure 3 ). The SCC, milk fat percentage, and milk protein percentage were $141 \pm 48(\times 1,000 / \mathrm{mL}), 4.3 \pm 0.1$, and $3.1 \pm 0.07$, respectively, and were not affected by UFM $(P>0.50)$.

\section{DISCUSSION}

We observed both an acute and long-term increase in milk production from the $4 \times$ side of the mammary gland in response to UFM. To compare our results with previous work that did not use a half-udder design, we multiplied the difference between the right and left udder halves by 2 (Table 1). After correcting milk yield to the equivalent of a whole-udder basis, the acute and long-term milk yield responses to frequent milking that we observed were consistent with those reported by Hale et al. (2003). However, we observed greater persistency in the milk yield response, which lasted throughout lactation. That our observations were similar to those of Hale et al. (2003) indicated that the increase in milk yield with frequent milking during early lactation in dairy cows was regulated by mechanisms within the mammary gland. The consistency in results validates the use of a UFM model for experiments investigating frequent milking during the early lactation of dairy cows. After validating the UFM model, we conducted power calculations and determined that we would have $82 \%$ power to detect a $0.90-\mathrm{kg}$ difference in milk production between udder halves using 6 cows. To obtain this same level of power using cow groups, we would need 53 cows. Our calculations illustrate the extremely high power and efficiency of the unilateral approach, and this has major implications with respect to the use of animals and associated expenses. 


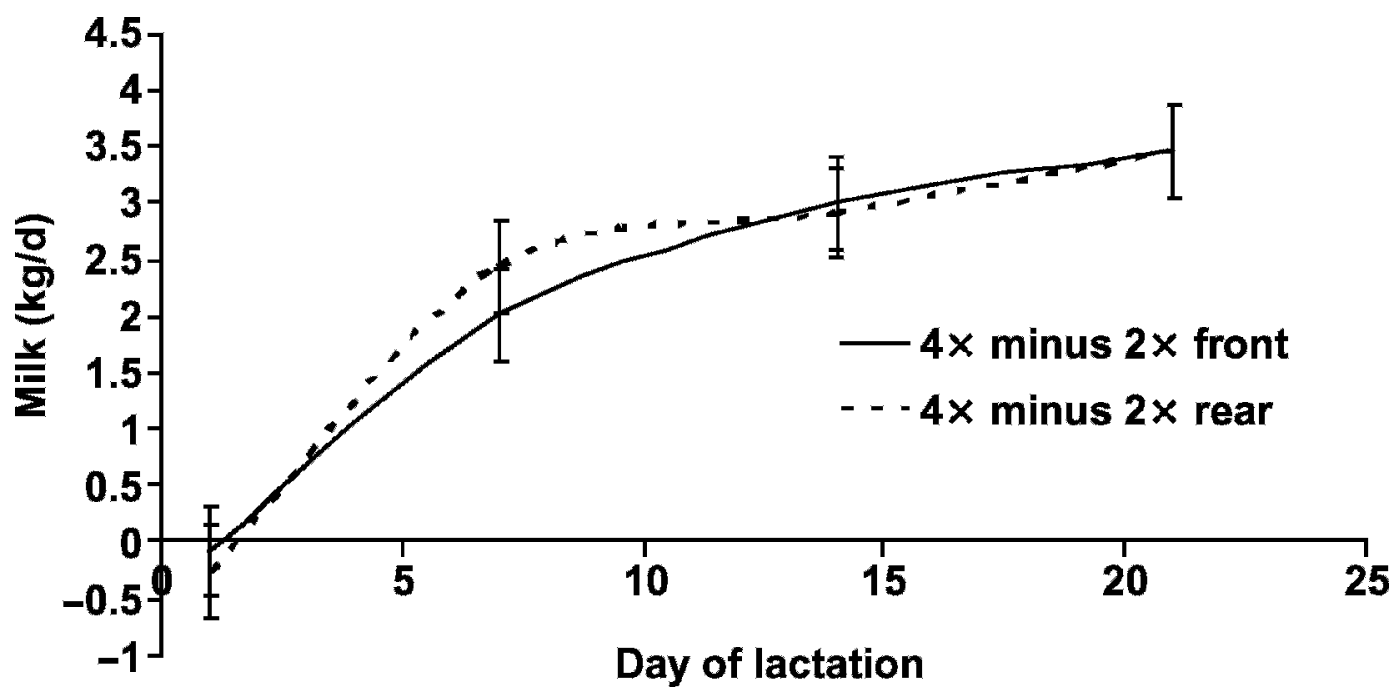

Figure 1. Difference in milk production between the right and left quarters of 4 cows assigned to unilateral frequent milking [twice daily milking of the left side (2×), 4 times daily milking of the right side $(4 \times)$ ] for $\mathrm{d} 1$ to 21 of lactation. Quarter milk yields were recorded on $\mathrm{d} 1,7,14$, and 21 of lactation, and milk production from the $2 \times$ side was subtracted from that of the $4 \times$ side. Milk yield increased similarly in the $4 \times$ front and rear quarters of the udder.

Two recent studies have reported no effect of frequent milking during early lactation on milk production (Fernandes et al., 2004; VanBaale et al., 2005). These findings conflict with the results of the current study, as well as with the results of previous studies (Bar-Peled et al., 1995; Hale et al., 2003; Dahl et al., 2004). This inconsistency in results illustrates the importance of a well-controlled experimental model; therefore, a UFM model is ideal for investigating frequent milking during early lactation.
Several possible explanations can be given for the observed increase in milk production with UFM. One possibility is that there is an increase in blood flow to the $4 \times$ side of the mammary gland, which would allow for increased exposure to the blood supply and to lactogenic hormones in circulation. Two arguments against blood flow exist: Although milk yield and blood flow are sometimes positively correlated, an increase in blood flow to the mammary gland does not always enhance milk production (reviewed in Prosser et al., 1996). Sec-

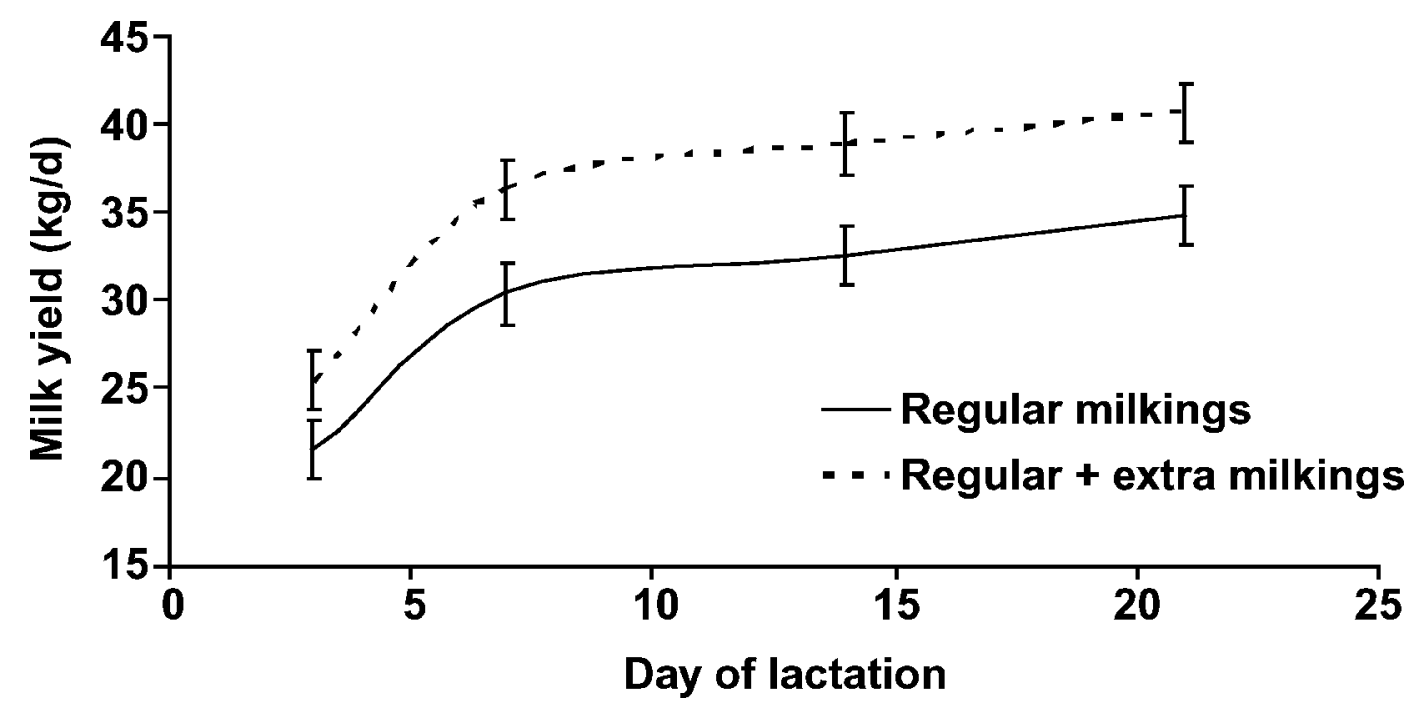

Figure 2. Milk production at regular and extra milkings of cows assigned to unilateral frequent milking [twice daily milking of the left side $(2 \times), 4$ times daily milking of the right side (4x)] for $\mathrm{d} 1$ to 21 of lactation. Regular milkings were at 0230 and $1430 \mathrm{~h}$, and extra milkings were at 0530 and $1730 \mathrm{~h}$. During the extra milking, only the right side of the udder was milked. 


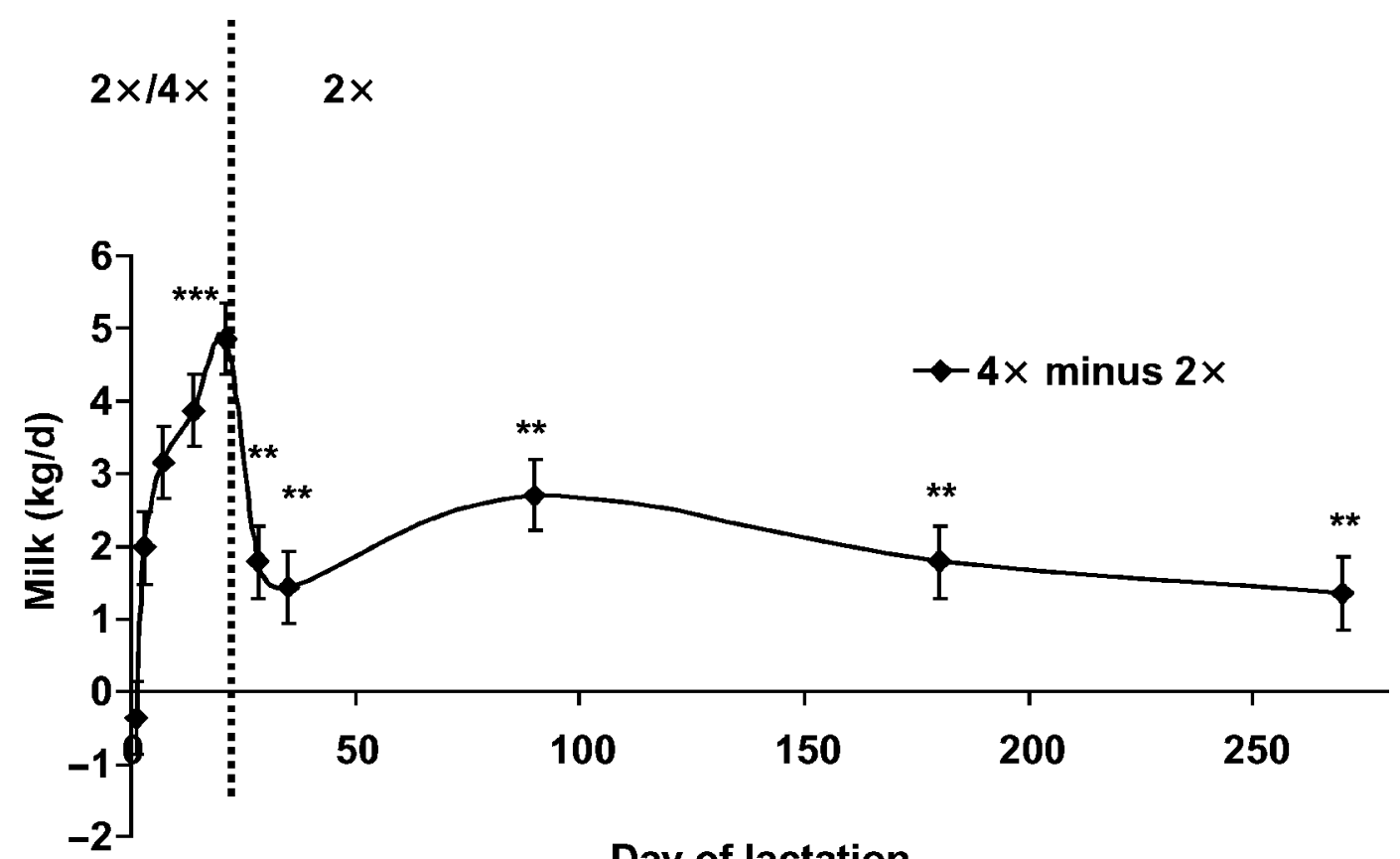

Day of lactation

Figure 3. Difference in milk production between the right and left udder halves of 10 cows assigned to unilateral frequent milking [UFM; twice daily milking of the left side $(2 \times), 4$ times daily milking of the right side $(4 \times)$ ] for $\mathrm{d} 1$ to 21 of lactation. Quarter milk production was measured throughout the lactation, and milk production from the $2 \times$ side was subtracted from that of the $4 \times$ side. There was no difference in milk production between udder halves on d 1 of lactation $(P>0.60)$. Milk production in the $4 \times$ udder half increased dramatically $(P<$ $0.001)$ during UFM and was greater than that of the $2 \times$ udder half through 270 DIM $(P<0.01)$.

ond, if an increase in vascular development is mediating the milk yield response, we would not expect an immediate decrease in milk production following cessation of UFM, but would expect more of a gradual decline as the vasculature regressed. Another possibility is that the capacity of the $4 \times$ side of the udder was increased with frequent milking, which could support a higher level of milk production. Although it has been established that mammary capacity is correlated with milk production (Ayadi et al., 2003), milk secretion is not limited by mammary capacity until about $12 \mathrm{~h}$ after milking (Knight et al., 1994). Therefore, it is unlikely

Table 1. Validation of a unilateral frequent milking model (UFM) ${ }^{1}$

\begin{tabular}{lll}
\hline & $\begin{array}{l}\text { Days } \\
1 \text { to } 21,\end{array}$ & $\begin{array}{l}\text { Days } \\
22 \text { to } 270, \\
\mathrm{~kg} / \mathrm{d}\end{array}$ \\
\hline $\mathrm{kg} / \mathrm{d}$ & +3.5 & +1.8 \\
UFM observed $2 \times$ & +7.1 & +3.6 \\
UFM adjusted, observed $\times 2$ & +8.6 & +2.6 \\
Hale et al. (2003) & +3 \\
\hline
\end{tabular}

${ }^{1}$ Twice daily milking of the left side $(2 \times), 4$ times daily milking of the right side $(4 \times)$ for $d 1$ to 21 of lactation. Observed milk yield response in the current study was adjusted to a whole-udder basis and compared with the observations of Hale et al. (2003), who used cow groups. The observed milk yield response to $4 \times$ milking was consistent across the 2 experiments; however, the persistency of the response was greater in the current study. that an increase in mammary capacity contributed to differences in milk production between udder halves during the short milking intervals (9 and $3 \mathrm{~h}$ ) used in our study. Because milk production is ultimately a function of mammary cell number and activity, we speculate that the enhanced milk production observed with UFM is the result of an increase in either or both of these factors in the $4 \times$ side of the udder. Studies currently being conducted in our laboratory could enable us to determine the mechanism(s) by which UFM increases milk production.

We did not observe an effect of UFM on the SCC or on the percentages of milk fat and milk protein. Based on previous data (Hale et al., 2003), we did not expect an effect of frequent milking on the SCC; however, we did expect a decrease in the percentages of milk fat and milk protein in the $4 \times$ side relative to the $2 \times$ side. Milk samples were collected at the afternoon milking. Thus, they did not represent a composite sample of all 4 milkings. This may explain why we did not observe a decrease in the fat and protein percentages in milk from the $4 \times$ udder half.

\section{CONCLUSIONS}

We conclude that frequent milking of dairy cows during early lactation increases milk production via mecha- 
nisms within the mammary gland. In addition, a UFM model is a valid and efficient model for use in experiments investigating frequent milking during early lactation.

\section{ACKNOWLEDGMENTS}

The authors thank Megan Richmond and university farm staff for help with animal handling, and Alan Howard for statistical support. This research was funded by United States Department of Agriculture Hatch Grant VT-H01112.

\section{REFERENCES}

Ayadi, M., G. Caja, X. Such, and C. H. Knight. 2003. Effect of omitting one milking weekly on lactational performances and morphological udder changes in dairy cows. J. Dairy Sci. 86:2352-2358.

Bar-Peled, U., E. Maltz, I. Bruckental, Y. Folman, Y. Kali, H. Gacitua, A. R. Lehrer, C. H. Knight, B. Robinzon, and H. Voet. 1995. Relationship between frequent milking or suckling in early lactation and milk production of high producing dairy cows. J. Dairy Sci. 78:2726-2736.

Claesson, O., A. Hansson, N. Gustafsson, and E. Brannang. 1959 Studies on monozygous cattle twins. XVII. Once-a-day milking compared with twice-a-day milking. Acta Agric. Scand. 8:38-58.
Dahl, G. E., R. L. Wallace, R. D. Shanks, and D. Lueking. 2004. Hot topic: Effects of frequent milking in early lactation on milk yield and udder health. J. Dairy Sci. 87:882-885.

Erdman, R. A., and M. Varner. 1995. Fixed yield responses to increased milking frequency. J. Dairy Sci. 78:1199-1203.

Everitt, G. C., and D. S. Phillips. 1971. Calf rearing by multiple suckling and the effects on the lactation performance of the cow. Proc. N. Z. Soc. Anim. Prod. 31:22-40.

Fernandes, J., C. M. Ryan, D. M. Galton, and T. R. Overton. 2004. Effects of milking frequency during early lactation on performance and health of dairy cows. J. Dairy Sci. 82(Suppl.1):424. (Abstr.)

Hale, S. A., A. V. Capuco, and R. A. Erdman. 2003. Milk yield and mammary growth effects due to increased milking frequency during early lactation. J. Dairy Sci. 86:2061-2071.

Hillerton, J. E., C. H. Knight, A. Turvey, S. D. Wheatley, and C. J. Wilde. 1990. Milk yield and mammary function in dairy cows milked four times daily. J. Dairy Res. 57:285-294.

Knight, C. H., D. Hirst, and R. J. Dewhurst. 1994. Milk accumulation and distribution in the bovine udder during the interval between milkings. J. Dairy Res. 61:167-177.

Morag, M. 1973. Two and three times-a-day milking of cows. Acta Agric. Scand. 23:252-260.

Prosser, C. G., S. R. Davis, V. C. Farr, and P. Lacasse. 1996. Regulation of blood flow in the mammary microvasculature. J. Dairy Sci. 79:1184-1197.

VanBaale, M. J., D. R. Ledwith, J. M. Thompson, R. Burgos, R. J. Collier, and L. H. Baumgard. 2005. Effect of increased milking frequency in early lactation with or without recombinant bovine somatotropin. J. Dairy Sci. 88:3905-3912. 